DOI: 10.4274/tpa.45.315

\title{
Gıdalardaki katkı maddeleri
}

Food additives

Tülay Erkan

İstanbul Üniversitesi, Cerrahpaşa Tıp Fakültesi Çocuk Gastroenteroloji, Hepatoloji ve Beslenme Bilim Dalı, İstanbul, Türkiye

\section{özet}

Gıda katkı maddeleri, tek başına gıda olarak tüketilmeyen, ancak gıdanın hazırlanması, tasnifi, işlenmesi, ambalajlanması, taşınması, depolanması ve dağıtımı sırasında niteliklerini korumak, düzeltmek veya istenmeyen değişikliklere engel olmak amacıyla kullanılmasına izin verilen maddeler olarak tanımlanır. Kullanım amacı gıdaların raf ömrünün uzatılması, gıda niteliklerinin korunması, duyusal özelliklerin düzeltilmesi/geliştirilmesi, sağlık açısından olabilecek bazı risklerin önlenmesi, gıda kayıplarının azaltılması, teknolojik gereklilik olması, gıda çeşitliliğinin artıııması, insan sağığının korunmasıdır. Gıda katkı maddeleri renklendiriciler, tatlandııcılar ve bunların dışındaki katkı maddeleri şeklinde olmak üzere üç ana başlık altında gruplandırımıştır. Gıda katkı maddelerinin kullanımı yasalarla düzenlenmektedir. Bu düzenlemelerin amacı, besinlerde kullanılan katkı maddesinin kötü kullanımını ve sağlık üzerinde oluşabilecek kötü etkilerini önlemektir. Kullanılmaları kaçınılmaz hale gelen bu katkı maddeleri konusunda bilinçlenmemiz gerekli olmuştur. Gıdaların etiket kontrolünün yapılması ve satış koşullarına dikkat edilmesi oldukça önemlidir. (Türk Ped Arş 2010; 45: 315-8)

Anahtar sözcükler: Gıda, denetim, katkı, renklendirici, sağlık, tatlandırıcı

\section{Summary}

Food additives are defined as substances which aren't consumed alone as food, but are permitted to be used to protect, fix and prevent unwanted changes of food during preparation, classification, processing, packaging, transportation, storage and distribution of them. The purpose is to extend the shelf life of foods, to preserve the food qualities, to improve/develop sensory properties, to prevent the health risks, to reduce food losses, to have the technological requirement, to increase food diversity, to protect the human health. Food additives are grouped under three main headings to be in the form of colorants, sweeteners and other additives. The use of food additives is regulated by laws. The purpose of these regulations is to prevent poor use of food additives and their adverse effects on health. Because the use of food additives has been became inevitable, the awareness has became necessary. Control of food label and sale conditions are very important considerations. (Turk Arch Ped 2010; 45: 315-8)

Key words: Food, control, additive, colorants, sweeteners, health

\section{Giriş}

Gıda katkı maddeleri, Türk Gıda Kodeksi yönetmeliğine göre, tek başına gıda olarak tüketilmeyen, gıda ham veya yardımcı maddesi olarak kullanılmayan, tek başına besleyici değeri olan veya olmayan, seçilen teknoloji gereği kullanılan işlem veya üretim sırasında kalıntı veya türevleri işlenmiş maddede bulunabilen, gıdanın hazırlanması, tasnifi, işlenmesi, ambalajlanması, taşınması, depolanması ve dağııımı sırasında gıda maddesinin tat, koku, görünüş, yapı ve diğer niteliklerini korumak, düzeltmek veya istenmeyen değişikliklere engel olmak amacıyla kullanımasına izin verilen maddeler olarak tanımlanır $(1,2)$. Ancak gıdaların besin değerini yükseltmek ya da hile amacıyla katılan maddeler bu gruba girmezler (3).

Gıda katkı maddeleri çok eski yıllardan beri bilinmektedir. Tarihsel gelişime bakıldığında tuz ve odun tütsüsünün bilinen en eski katkı maddeleri olduğu görülmektedir (4). Gıda boyaları tarihte ilk kez Mısırlılar tarafından M.Ö 3500

Yazışma Adresi/Address for Correspondence: Dr. Tülay Erkan, Vişnezade Mah. Kireçhane Sok.

Türker Apt. No: 9/4 Beşiktaş, İstanbul, Türkiye E-posta: tulerkan@gmail.com Geliş Tarihi/Received: 16.08.2010 Kabul Tarihi/Accepted: 14.09.2010 Türk Pediatri Arşivi Dergisi, Galenos Yayınevi tarafindan basilmıştr. / Turkish Archives of Pediatrics, published by Galenos Publishing. 
yıllarında kullanılmıştır. Milattan önce 3000 yıllarında ilk kez eti saklamak için yalnızca tuz, daha sonra M.Ö 900 'lerde hem tuz, hem de odun tütsüsü gıda saklamada kullanılmıştır. Ortaçağda ise gıdalara nitrat eklenerek, hem botulizm önlenmiş, hem de etin rengi daha sağ|ıkl hale getirilmiştir (4). Bu maddelerin birçoğu bugün de üç temel işlevi görmektedir: kozmetik, koruyuculuk, işleme. Zaman içinde bu katkı maddelerinin sayıları çok artmış ve 4000'leri bulmuştur (5).

Gıda katkı maddelerinin kullanım amacı gıdaların raf ömrünün uzatılması, gıda niteliklerinin korunması, gıdaların besleyici değerlerinin korunması, duyusal özelliklerin düzeltilmesi/geliştirilmesi, sağlık açısından olabilecek bazı risklerin önlenmesi, gıda kayıplarının azaltılması, teknolojik gereklilik olması, gıda çeşitliliğinin artırıması, insan sağlığının korunmasıdır (6).

Tanımda belirtilen kullanım amaçlarına uygun olacak şekilde gıda katkı maddeleri dört alt başlıkta toplanır (7)

1) Kaliteyi koruyarak raf ömrünü uzatanlar (koruyucular)

a) Antimikrobiyaller (nitrit, nitrat, benzoik asit, propiyonik asit)

b) Antioksidanlar (bütillenmiş hidroksiyanazol-BHA, bütillenmiş hidroksitolüen-BHT, askorbik asit, kükürt dioksit)

2) Yapı ve hazırlama, pişme özelliğini geliştirenler

a) $\mathrm{pH}$ ayarlayıcılar

b) Topaklanmayı önleyenler ( silikat, magnezyum oksit, magnezyum karbonat)

c) Emülsiyonu sağlayanlar (lesitin, mono ve digliseritler)

d) Mayalanmayı sağlayanlar

e) Nem ayarlayıcılar

f) Olgunlaştırıcılar

g) Ağartıcılar, dolgu maddeleri, köpük ayarlayıcılar, parlatıcılar

h) Stabilizörler, kıvam artıııılar, tatlandırıcılar

3) Aroma ve renk geliştirenler

a) Çeşni artırıcılar (Monosodyum glutamat-MSG)

b) Çeşni vericiler (aroma maddeleri)

c) Renklendiriciler (tartrazin, indigotin)

4) Besin değerini koruyan, geliştirenler

a) Diyette eksik olabilecek besin öğelerini ekleme (A, D vitaminleri)

b) İșleme sırasında kaybolan besin öğelerini yerine koyma (B1, B2, niyasin).

Her ülkede katkı kullanımını düzenleyen bir ulusal yönetmelik ve bunu uygulayan resmi ulusal kuruluşlar bulunur. Avrupa Birliği ortak yönetmeliğinde gıda katkı maddeleri üç ana başlık altında gruplandırılmıştır: renklendiriciler, tatlandıııcılar ve bunların dışındaki katkı maddeleri (8).

Gıda katkı maddelerinin kullanımı yasalarla düzenlenmektedir. Bu düzenlemelerin amacı, besinlerde kullanılan katkı maddesinin kötü kullanımını ve sağlık üzerinde oluşabilecek kötü etkilerini önlemektir. Dünyada, renklendiriciler, tatlandırıcılar ve bunların dışındaki katkı maddeleri ile ilgili çalışmalar, Birleşmiş Milletler'e bağlı Gıda ve Tarım Örgütü (FAO) ile Dünya Sağlık Örgütü'nün birlikte kurduğu ve Türkiye'nin de üyesi olduğu Uluslararası Gıda Kodeks Komisyonu (Codex Alimantarius Comission=CAC) kapsamında yürütülmektedir. Uluslararası Gıda Kodeks Komisyonu'nun oluşturduğu Gıda Katkı Maddeleri Uzmanlar Komitesi (Joint Expert Commitee on Food Additives= JECFA) her türlü gıda katkı maddesinin tüm etkilerini belirlemek için söz konusu maddeleri uzun süreli olarak deney hayvanları üzerinde toksikolojik, karsinojenik, teratojenik ve mutajenik etkileri açısından inceler $(3,7)$. Katkı maddesinin yasalıı kazanabilmesi için farmakolojik deneylerin fare dışında iki değişik hayvanın üzerinde yapılmış olması zorunludur. Besinlere katılacak miktarın hayvanlarda hiç toksik etki göstermeyen en yüksek dozun 1/100, 1/200 kadarı olması gereklidir (2). Toksikoloji biliminin öncülerinden Paracelsus'a (4) göre her madde toksindir, toksin ile toksin olmayanı birbirinden ayıran dozdur.

Sağlığa zararlı olmadığına karar verilen katkı maddesi için "günlük tüketilebilir miktar-(Acceptable daily intake= ADI)" değerleri kullanılır ve elde edilen sonuçlara göre de gıdalarda kullanılmasında sakınca görülmeyen katkı maddeleri ve kullanım sınırları belirlenir. Katkı maddesinin ADI değeri toksikolojik testlerle saptanır (7). Deney hayvanlarına öldürücü dozda (deney hayvanlarının \%50'sinin ölümüne neden olan doz) katkı maddesi verildikten sonra, doz giderek azaltılarak doz-yanıt ilişkisi araştıııı. Her dozda katkı maddesinin emilimi, metabolizması ve atımı incelenir. Çalışmalar sonucunda katkı maddesinin hiçbir etkisinin bulunmadığı bir doz elde edilemezse katkı maddesinin besinlere katılmasına izin verilmez.

Hazır gıdaların paketleri üzerinde, kullanım amaçlarına göre katkı maddelerinin sınıfları, bunu izleyen özel adlar ve "E" (European) numaraları ile belirtilir. "E" numaraları Avrupa Birliği ülkelerinde gıda katkı maddelerini kodlamak için oluşturulmuştur (Tablo 1). Güvenilir gıda katkı maddeleri listesinde yer alan tüm katkılar "E" kodunu taşır ve toksikolojik açıdan güvenilir demektir. "E" harfi tüketici için sağlık açısından güvencedir (8). 
Genelde katkı maddelerinin birçok yan etkileri olabilmektedir, alerjik reaksiyonlar da bunlardan biridir (Tablo 2) (9-11). Katkı maddeleri bu reaksiyonları uyarmaktan çok, önceden varolan duyarlıı̆ı arttırmaktadır. İngiltere'de 15 000 kişiyi kapsayan bir çalışmada nüfusun \%0,010,23'ünün bu maddelere karşı duyarlı olabileceği saptanmıştır (9). Bu maddelerinin alerjik reaksiyon oluşturma mekanizması tam olarak anlaşılamamıştır. Besin renklendiricilerinin aler $\mathrm{jik}$ mekanizmadan çok, duyarlı kişilerde doğrudan farmakolojik etkiyle, ürtikerde histamin ve prostaglandinleri salgıladığı düşünülmektedir (12). Renklendiricilerden bazıları astım, deri döküntüleri, hiperaktivite ve migrene yol açabilir. İzin verilen renklendiriciler ülkeden ülkeye değişebilir (13). Aroma artırıcı maddelerden bazıları baş dönmesi, çarpıntı yapabilir (2). Bu maddelerin karsinojenik etkileri ileri sürülmekle beraber kanıtlanamamıştır (12). Koruyucu olarak kullanılan nitrat ve nitrit kanserojen nitrozo bileşiklerinin oluşumuna araclık etmektedir. Nitratın ADI değeri 0-5 mg/kg, nitritin ADI değeri 0-0,2 mg/kg olarak belirlenmiştir. Günlük aldığımı nitrat ve nitritin, \%20'si gıda katkı maddelerinden gelmektedir $(2,14)$.

Dünya Sağlık Örgütü ve FAO ilgili kuruluşları tarafından kabul edilen değerlerden yararlanılarak her ülkenin sağlık yetkeleri katkı maddelerinin katılacağı gıdaları ve katılma miktarını kendi ülkelerinin koşullarına göre belirler. Ancak esas önemli nokta, bu belirlemeden sonra bu maddelerin

\begin{tabular}{|l|l|}
\hline \multicolumn{2}{|c|}{ Tablo 1. "E" numara sistemi ile gıda katkı maddelerinin } \\
sınıflandırılması
\end{tabular}

yönetmeliğe uygunluğunun sürekli denetlenmesidir (15). Türkiye'de 1995 tarihinde yürürlüğe giren 560 sayılı kanun hükmünde kararname ile bu yetki önce Sağlık Bakanlığına bırakılmıştır (16). Gıda Katkı Maddeleri Tüzüğü ile yürütülen bu işlemler daha sonra 2004 yılında Tarım ve Köyişleri Bakanlığı'na devredilmiştir (17). Bu bakanlığa bağlı olarak Türk Gıda Kodeksi Yönetmeliği 1997 yılında yürürlüğe girmiştir ve halen Gıda Kodeksi ve Beslenme Şube Müdürlüğü'nce çalışmalar yapılmaktadır. Üretim aşamasındaki kontrol ve gıda katkı madde kullanımının denetimi Tarım ve Köyişleri Bakanlığı'na devredilmiş olmakla birlikte pazar aşamasındaki kontrol Sağlık Bakanlığı'na ve bazı bölgelerde Sağlık Bakanlığı ile birlikte yerel yönetimlere verilmiştir. Her üretici firma yılda iki defa denetlenmektedir.

Ülkemizde yaklaşık 300 adet gıda katkı maddesinin kullanımına izin verilmekte olup Amerika Birleşik Devletleri'nde bu sayı yaklaşık 2800'dür (6).

Günümüz yaşam koşullarında hazır gıdalar fazlaca tüketilmektedir. Ayrıca gıda katkı maddesi olmadan üretilen besinler daha çabuk bozulmakta ve bunların maliyeti de daha fazla olmaktadır. Dolayısıyla kullanımaları kaçınılmaz hale gelen bu katkı maddeleri konusunda bilinçlenmemiz gerekli olmuștur. Gıdaların etiket kontrolünün yapılması ve satış koşullarına dikkat edilmesi oldukça önemlidir.

Bu bağlamda alınan her gıdanın veya ürünün etiket bilgilerinin okunması alışkanlık haline getirilmeli, en azından üretim bilgileri içermeyen ürünler satın alınmamalıdır. Ilı dikkat edilecek kısım Tarım ve Köyişleri Bakanlığı'nın vermiş olduğu üretim iznidir. Bu izinin tarih ve sayısına bakılmalıdır. Tarım ve Köyișleri Bakanlığı'ndan üretim izni almış ürünün denetlenmiş olduğundan ve katkı maddelerini doğru kullandığından; yani bu maddelerin, izin verilen besinde ve izin verilen miktarlarda kullanıldığından emin olunmalıdır.

Tablo 2. Gıda katkı maddelerine ait görülebilecek yan etkiler

\begin{tabular}{lll} 
Katkı maddesinin adı & Kullanım nedeni & \multicolumn{1}{c}{ Yan etkisi } \\
\hline Aspartam & Tatlandıııı & $\begin{array}{l}\text { Anjiyoödem, göz kapaklarında, dudaklarda, } \\
\text { ellerde ve ayaklarda şişme, menstrüel düzensizlik }\end{array}$ \\
\hline Benzoatlar & Koruyucu & Baş ağrısı, ürtiker, bağırsak bozukluğu \\
\hline BHA, BHT & Antioksidan & Ürtiker, kanser (?) \\
\hline Gıda boyaları & Renklendirici & Ürtiker, astım atağı \\
\hline Monosodyum glutamat (MSG) & Lezzet artıııı & $\begin{array}{l}\text { Başağrısı, bulantı-ishal, terleme, göğüste } \\
\text { sıkışma, ağır astım atağı }\end{array}$ \\
\hline Nitrat ve nitritler & Koruyucu & Baş ağrısı, ürtiker \\
\hline Parabenler & Koruyucu & Deride kızarıklık, şişlik, kaşıntı ve ağrı. \\
\hline Sülfitler & Koruyucu & Göğüs ağrısı, ürtiker, karında kramp, \\
& & kan basıncı düşmesi, halsizlik, nabız artışı \\
\hline
\end{tabular}




\section{Kaynaklar}

1. htpp://www.kkgm.gov.tr/kanun/560html. Erişim: 10.08.2010.

2. Çalışır ZE, Çalışkan D. Gıda katkı maddeleri ve insan sağlığ üzerine etkileri. Ankara Ecz Fak Derg 2003; 32: 193-206.

3. Bağcı T. Gıda katkı maddeleri ve sağlığımız üzerine etkileri. Hacettepe Tıp Dergisi 1997; 28: 18-23.

4. Atman ÜC. Gıda katkı maddeleri ve gıda kontrolü. Sted 2004; 13: 86-8.

5. Doğruyol H. Gıdalardaki katkı maddeleri ve zararları: çocukluk hiperaktivitesi. Güncel Pediatri 2006; 2: 42-8.

6. Özkaya İ. Gıda katkı maddeleri ve toksinler. İçinde: Oşar Z, Erkan T (yazarlar). Sağlıkta ve Hastalıkta Beslenme. İstanbul: Deomed Medikal Yayınclık 2004: 39-44.

7. Yurttagül M, Ayaz A. Katkı maddeleri: yanlıșlar ve doğrular. Sağlık Bakanlığı yayını no: 727. 1. Basım. Ankara: Klavmat Matbaacılık 2008

8. http://www.efsaeuropa.eu/. Erişim tarihi: 01.11.2010

9. Randhawa S, Bahna SL. Hypersensitivity reactions to food additives. Curr Opin Allergy Clin Immunol 2009; 9: 278-83.

10. Wilson BG, Bahna SL. Adverse reactions to food additives. Ann Allergy Asthma Immunol 2005; 95: 499-507.
11. Young E, Patel S, Stoneham M. The prevalence of reaction to food additives in children with atopic symptoms. Allergy 1994; 49: $31-7$.

12. Zuberbier T, Pfrommer C, Specht K, et al. Aromatic components of food as novel eliciting factors of pseudoallergic reactions in chronic urticaria. J Allergy Clin Immunol 2002; 109: 343-8.

13. Elhkim MO, Héraud F, Bemrah N, et al. New considerations regarding the risk assessment on Tartrazine. An update toxicological assessment, intolerance reactions and maximum theoretical daily intake in France. Regul Toxicol and Pharmacol 2007; 47: 308-16.

14. Hord NG, Tang Y, Bryan NS. Food sources of nitrates and nitrites: the physiologic context for potential health benefits. $J$ Clin Nutr 2009; 90: 1-10.

15. Giray H, Soysal A. Türkiye'de gıda güvenliği ve mevzuatı. Kor Hek 2007; 6: 445-90.

16. 560 sayılı gıdaların üretimi, tüketimi ve denetlenmesine dair kanun hükmünde kararname. Resmigazete; 28.06.1995, sayı: 22327.

17. 5179 sayılı gıdaların üretimi, tüketimi ve denetlenmesine dair kanun hükmünde kararnamenin değiștirilerek kabülü hakkında kanun. Resmi gazete; 05.06.2004, sayı: 25483. 